\title{
Variables associated with the prevalence of anti-Leishmania spp. antibodies in dogs on the tri-border of Foz do Iguaçu, Paraná, Brazil
}

\author{
Variáveis associadas à prevalência de anticorpos anti-Leishmania spp. em cáes na tríplice fronteira \\ de Foz do Iguaçu, Paraná, Brasil
}

\begin{abstract}
Renata Cristina Ferreira Dias ${ }^{1 *}$; Vanete Thomaz-Soccol²; Aline Kuhn Sbruzzi Pasquali²; Silvana Maria Alban²; Ricardo Cancio Fendrich ${ }^{2}$; Eliane Maria Pozzolo ${ }^{3}$; Luciana Chiyo ${ }^{4}$; Alceu Bisetto Júnior ${ }^{5}$; Fernanda Pinto Ferreira ${ }^{1}$; Stela Silva Desto ${ }^{1}$; Roberta Lemos Freire'; Regina Mitsuka-Breganó ${ }^{1}$; Italmar Teodorico Navarro ${ }^{1}$
\end{abstract}

\author{
${ }^{1}$ Departamento de Medicina Veterinária Preventiva, Universidade Estadual de Londrina - UEL, Londrina, PR, Brasil \\ ${ }^{2}$ Engenharia de Bioprocessos e Biotecnologia, Universidade Federal do Paraná - UFPR, Curitiba, PR, Brasil \\ ${ }^{3} 9^{\circ}$ Regional de Saúde, Foz do Iguaçu, PR, Brasil \\ ${ }^{4}$ Centro de Controle de Zoonoses, Prefeitura de Foz do Iguaçu, Foz do Iguaçu, PR, Brasil \\ ${ }^{5}$ Secretaria da Saúde do Estado do Paraná, Curitiba, Paraná, Brasil
}

Received April 03, 2018

Accepted June 26, 2018

\begin{abstract}
The aim of this study was to investigate the occurrence of anti-Leishmania spp. antibodies in dogs from localities in the city of Foz do Iguaçu, Paraná state, Brazil, on the border with Argentina and Paraguay. Blood samples dogs were collected to perform the following serologic tests: immunochromatographic $\mathrm{DPP}^{\circledR}$ rapid test, indirect immunoenzymatic assay (ELISA) and indirect immunofluorescence assay (IFA). In 2012, 285 dogs were analyzed on Argentina border, and in 2013, serum samples from 396 dogs on the border of Paraguay were collected. Using ELISA for screening and IFA for the confirmatory test, the results showed that the antibody prevalence was $1.8 \%(5 / 285)$ on the border of Argentina and 3.0\% (12/396) on Paraguay border. When using the DPP ${ }^{\circledR}$ for screening and ELISA as a confirmatory analysis, we observed a seroreagent prevalence in dogs of 2.5\% (7/285) on Argentina border and 5.1\% (20/396) on Paraguay border. The non-public collection of domestic waste $(\mathrm{p}=0.0004)$ was shown to be associated with leishmaniasis. This study shows the presence of leishmaniasis and suggest the emergence of canine visceral leishmaniasis in state of Paraná due to the confirmed occurrence of seroreactive dogs on Argentina and Paraguay border, which has environmental and geographical characteristics that favor the spread of the parasite.
\end{abstract}

Keywords: Zoonosis, one health, epidemiology, emergence.

\section{Resumo}

O objetivo deste estudo foi investigar a ocorrência de anticorpos anti-Leishmania spp. em cáes da cidade de Foz do Iguaçu, estado do Paraná, Brasil, fronteira com a Argentina e o Paraguai. Amostras de sangue de cães foram coletadas para realizaçâo dos seguintes testes sorológicos: teste rápido imunocromatográfico $\mathrm{DPP}^{\circledR}$, ensaio imunoenzimático indireto (ELISA) e ensaio de imunofluorescência indireta (IFI). Em 2012, 285 cães foram analisados na fronteira com Argentina e, em 2013, amostras de soro de 396 cáes na fronteira com o Paraguai. Utilizando ELISA para triagem e IFA para o teste confirmatório, os resultados mostraram uma prevalência de anticorpos de 1,8\% (5/285) na fronteira da Argentina e 3,0\% (12/396) na fronteira com o Paraguai. Ao usar o DPP ${ }^{\circledR}$ para triagem e ELISA como uma análise confirmatória, observou-se uma prevalência de cáes sororreagentes de 2,5\% (7/285) na fronteira com a Argentina e 5,1\% (20/396) na fronteira com o Paraguai. A não coleta pública de lixo doméstico $(\mathrm{p}=0,0004)$ mostrou-se associada à leishmaniose. Este estudo demonstra a presença de leishmaniose e sugere a emergência da leishmaniose visceral canina no estado do Paraná devido à ocorrência de cáes sororreagentes na fronteira Argentina e Paraguai, que possuem características ambientais e geográficas que favorecem a disseminação do parasito.

Palavras-chave: Zoonoses, saúde única, epidemiologia, emergência.

*Corresponding author: Renata Cristina Ferreira Dias. Departamento de Medicina Veterinária Preventiva, Universidade Estadual de Londrina, Rod. Celso Garcia Cid, Km 380, Campus Universitário, CEP 86057-970, Londrina,

PR, Brasil. e-mail: rcfdias14@gmail.com 


\section{Introduction}

Zoonotic visceral leishmaniasis (VL) is a disease with global distribution. In the Americas, the etiological agent responsible for this disease is the protozoan Leishmania infantum (Kinetoplastida, Trypanosomatidae) (NICOLLE, 1908; LAINSON \& SHAW, 1987; READY, 2014). In endemic areas, dogs are the reservoirs of greatest epidemiological importance as source of infection for the vectors (ASHFORD, 1996; DANTAS-TORRES, 2007; COSTA, 2011). The incidence of VL in humans is related to the number of canine visceral leishmaniasis (cVL) cases and the presence and density of sand fly species competent to transmit the parasite from dogs to humans (WERNECK, 2014; ORTIZ \& ANVERSA, 2015).

In Brazil, female phlebotomine sand flies of the species Lutzomyia longipalpis are the main vector responsible for the transmission of L. infantum (LAINSON \& RANGEL, 2005). This vector was first identified in the southern region of Brazil in São Borja, Rio Grande do Sul (RS), in 2009, but the first canine case was reported in 2008 (SOUZA et al., 2009; FIGUEIREDO et al., 2012). Entomological surveys in Paraná state have been performed for years, and no competent vectors were observed for VL (TEODORO et al., 2003; MEMBRIVE et al., 2004; TOMAZ-SOCCOL et al., 2009; TEODORO et al., 2010). Santos et al. (2012) identified for the first time Lu. longipalpis in the state, in the city of Foz do Iguaçu. One of the factors that may have led to the entrance of the vector in Paraná is that on the triple border of Brazil, Argentina and Paraguay are records of VL cases. Reports in Paraguay display an increase in the incidence of human VL (HVL), with the disease appearing in the province of Alto Paraná, a region bordering Foz do Iguaçu (CANESE, 2010; PARAGUAY, 2011). From May 2006 to July 2012, 103 HVL cases were notified in Argentina, and dogs infected with L. infantum were reported throughout almost the entire country (SALOMÓN et al., 2008, 2011; GOULD et al., 2013; BARROSO et al., 2015). On the Argentina border of Foz do Iguaçu, in the city of Puerto Iguazú, the presence of the vector $L$ u. longipalpis was verified in a study conducted in 2010 (SALOMÓN et al., 2011), and in 2013, the DNA presence of $L$. infantum was confirmed in samples of dogs from this city (ACOSTA et al., 2015).

Foz do Iguaçu is a vulnerable city to this zoonosis because of the great migratory flow, its border with countries with VL cases and the identification of the vector Lu. longipalpis (SANTOS et al., 2012). Therefore, the present study was developed to investigate the occurrence of anti-Leishmania spp. antibodies in dogs from localities close to the border of Argentina and Paraguay and to identify the variables associated with VL.

\section{Materials and Methods}

\section{Study area}

The city of Foz do Iguaçu had an estimated average population of 259,313 inhabitants in 2012 and 2013 (IBGE, 2012, 2013). It is located in the extreme west of Paraná State, on the border of Paraguay and Argentina, at latitude 2532'45 "S and longitude
543'07” W. Foz do Iguaçu shares borders with Itaipulândia (Brazil) in the north, Puerto Iguazú (Argentina) in the south, Santa Terezinha de Itaipu and São Miguel do Iguaçu (Brazil) in the east, and Ciudad del Este (Paraguay) in the west. It experiences a humid subtropical climate, with hot summers, rare frosts and rain during all months of the year. It has nine hydrographic watersheds, seven of which are circumscribed to the municipal perimeter, with the rivers Paraná, Iguaçu, Tamanduá, São João, Almada, M’Boicy and Monjolo (IBGE, 2016; FOZ DO IGUAÇU, 2017).

\section{Sampling site}

Due to the emergency appearance of cVL in Foz do Iguaçu, the study was initially performed with authorization from the Ninth Health Region, Paraná State, and was later approved by the Ethics Committee on Animal Use of Londrina State University (CEUA no. 22530.2013).

The method used to select the residences and to sample the dogs' blood involved selecting locations where sand fly traps were installed in entomological surveys performed by the Ninth Health Region prior to the collections. Houses were randomly chosen out of those in which a dog was present. For the blood collection, the owners signed a term of authorization and awareness and an epidemiological questionnaire that included information about the environment, origin of the animal and its clinical characteristics.

Firstly, from May 4th to 18th of 2012, collections were conducted in localities near the border of Argentina and the rivers Iguaçu and Paraná. In a second sampling stage, from June 17th to July 4th of 2013, blood was collected from dogs in localities close to the border of Paraguay and the Paraná river and from a few other localities far from the borders (Figure 1). The samples were processed at the Ninth Health Region, Paraná State, at the Department of Bioprocess Engineering and Biotechnology laboratory of the Federal University of Paraná (UFPR), and at the laboratory of Protozoology of the Department of Preventive Veterinary Medicine of the Londrina State University.

\section{Serodiagnosis}

To determine the presence of anti-Leishmnia spp. antibodies and to identify the prevalence of seroreagent animals for leishmaniasis, the serodiagnostics followed two criteria of the screening and confirmatory tests adopted by the Brazilian Ministry of Health: the enzyme-linked immunosorbent assay (ELISA) for screening with the immunofluorescence assay (IFA) as the confirmatory test recommended by the Surveillance and Control Program of Leishmaniasis until 2012, and in order to improve the cVL diagnostic technique this protocol was replaced for the $\mathrm{DPP}^{\circledR}$ rapid test $\left(\mathrm{DPP}^{\circledR}\right)$ for screening with the ELISA as a confirmatory test (BRASIL, 2006, 2011).

The $\mathrm{DPP}^{\circledR}$ test was performed using serum samples according to the manufacturer's protocol (Bio-Manguinhos/Fiocruz, Rio de Janeiro, BR). The ELISA test was standardized according to Maziero et al. (MAZIERO et al., 2014). The cut-off point was determined based on the average absorbance of four negative sera 


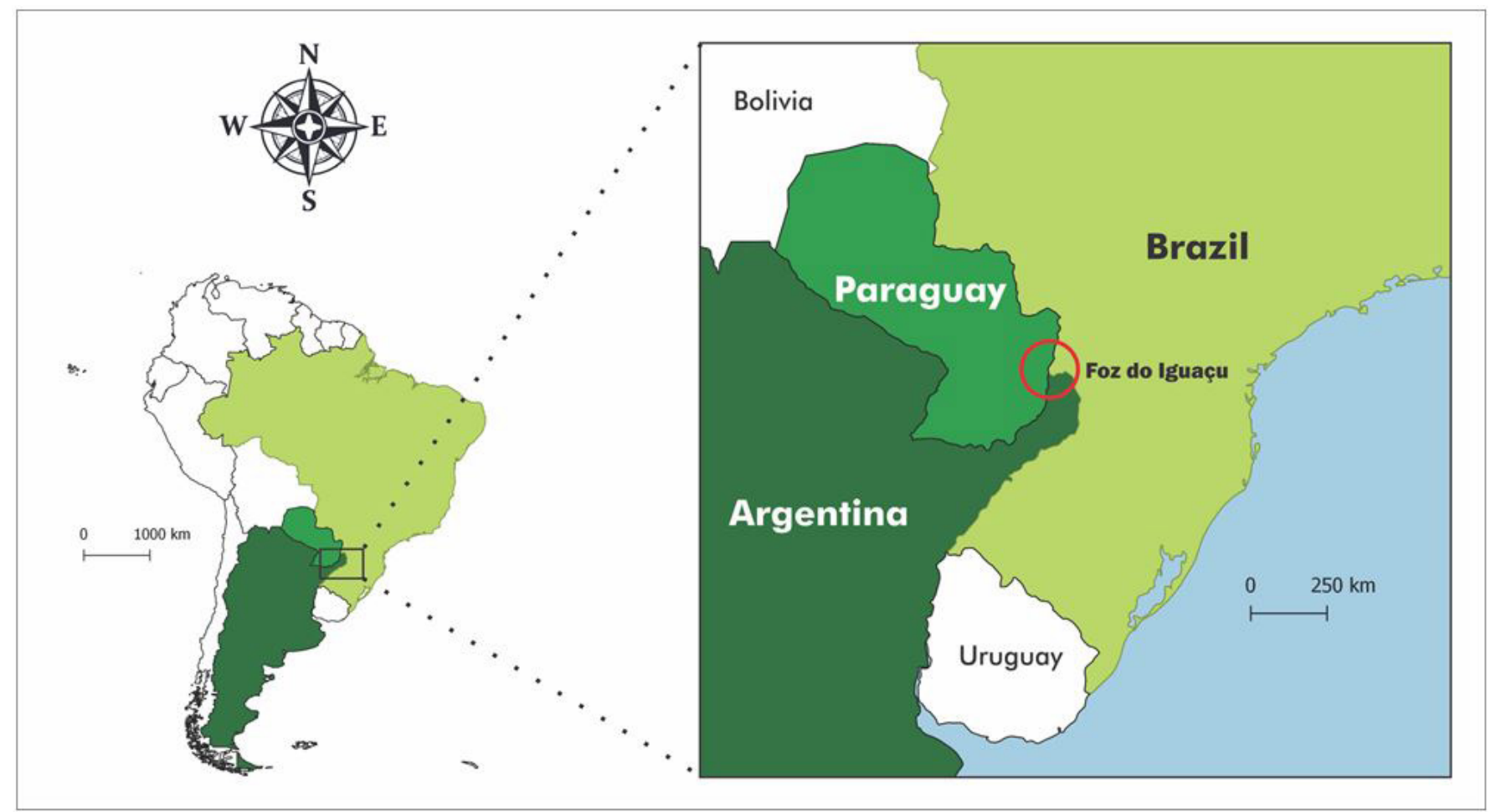

Figure 1. Map showing the location of the tri-border area: Foz do Iguaçu (Brazil) frontier with Puerto Iguaçu (Argentina) and Ciudad del Este (Paraguay).

(dogs born in Curitiba - Paraná) plus three standard deviations, repeated on each plate.

The IFA was standardized according to Marzochi et al. (1980), and the readings were performed under an epifluorescence microscope with a 40x objective. Sera were diluted from 20, and reagents with a titer greater than or equal to 40 were considered (MARZOCHI et al., 1980).

\section{Statistical analysis}

The EpiInfo 6 program (DEAN et al., 1994) was used to tabulate and analyze the variables that composed the epidemiological questionnaire along with the serological results found. For the univariate analysis, Pearson's Chi-square test for Independence or Fisher's Exact test were used. The significance level of 5\% ( $\mathrm{p}<0.05)$ was adopted to reject the null hypothesis, and the odds ratio (OR) as a measure of association with a $95 \%$ confidence interval (CI) was used.

\section{Results}

Of the 285 dogs analyzed for anti-Leishmania spp. antibodies on the border of Argentina, 3.2\% (9/285) were reagent for the $\mathrm{DPP}^{\circledR}$ test, $30.5 \%(87 / 285)$ for the ELISA, and 4.6\% (13/285) for IFA. Of the 87 reagent animals for ELISA, five (5/87) were also reagent for IFA and seven $(7 / 87)$ for $\mathrm{DPP}^{\circledR}$. Only one dog was reactive on all three serological tests.
Of the 396 dogs analyzed on the border of Paraguay for anti-Leishmania spp. antibodies, 7.6\% (30/396) were reagent for the DPP ${ }^{\circledR}$ test, $21.2 \%(84 / 396)$ for the ELISA and 4.3\% (17/396) for IFA. Of the 84 reagent animals for ELISA, 12 (12/84) were also reagent for IFA and $20(20 / 84)$ for $\mathrm{DPP}^{\circledR}$. Of the nine dogs that were seroreagent on all three tests, all were autochthonous, two were from the same residence and one dog was from a neighboring residence; all of the dogs were located in the central region of Foz do Iguaçu (Figure 2).

When we used the ELISA as a screening test and the IFA as confirmatory, the prevalence of anti-Leishmania spp. antibodies was $1.8 \%$ (5/285) on the border of Argentina and 3.0 (12/396) on the border of Paraguay. However, when $\mathrm{DPP}^{\circledR}$ was used as a screening test and ELISA as confirmatory, a seroreagent animal prevalence of $2.5 \%$ (7/285) was observed on the border of Argentina and $5.1 \%$ (20/396) on the border of Paraguay (Table 1).

Tables 2 and 3 show the epidemiological data and characteristics of the dogs on the borders of Argentina and Paraguay, respectively, and a significant difference in the non-public collection of domestic waste $(\mathrm{p}=0.0004 ; \mathrm{OR}=0.07 ; 95 \% \mathrm{CI}=0.02-0.30)$ was found only on the border of Paraguay (Table 3), demonstrating a variable risk of leishmaniasis in this area.

An analysis of the entire population of dogs (Table 4) showed that most of the animals were female, without an identified breed; were aged between two and eight years old and were from the city of Foz do Iguaçu. The majority lived in urban areas with woods very close to the household. In both collection regions, the presence of other animal species was verified in the peridomiciliary area and mainly included cats $(22.1 \%$ on the border of Argentina 


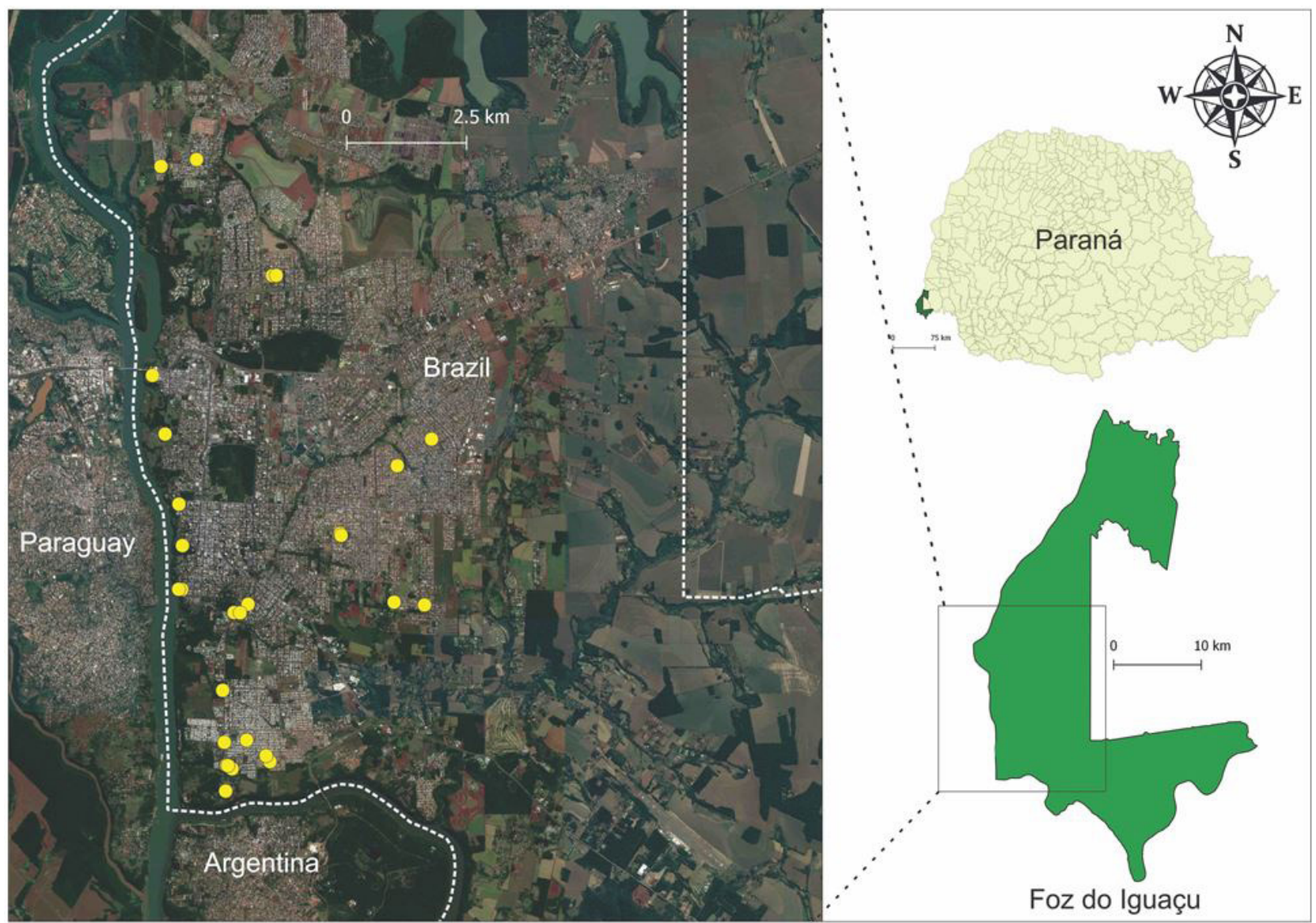

Figure 2. Dispersion of seroreactive dog samples in more than one serological test (immunochromatographic test, enzyme-linked immunosorbent assay and indirect immunofluorescence assay), in Foz do Iguaçu city, Paraná State, Brazil, 2012 - 2013.

Table 1. Prevalence of anti- $L$. infantum antibodies according to the immunochromatographic test $\left(\mathrm{DPP}^{\circledR}\right)$, the enzyme-linked immunosorbent assay (ELISA) and the indirect immunofluorescence assay (IFA), in dogs from localities close to the border region of Foz do Iguaçu city, Paraná, in Argentina and Paraguay, 2012 and 2013.

\begin{tabular}{ccccccccc}
\hline \multicolumn{1}{c}{ Region } & $\begin{array}{c}\text { Number of } \\
\text { serum samples }\end{array}$ & $\begin{array}{c}\text { DPP } \\
\text { \% }\end{array}$ & $\begin{array}{c}\text { ELISA } \\
\text { \% }\end{array}$ & $\begin{array}{c}\text { RIFI } \\
\text { \% }\end{array}$ & $\begin{array}{c}\text { ELISA }^{\mathbf{1}} \\
\text { RIFI \% }\end{array}$ & $\begin{array}{c}\text { DPP }^{\circledR 2} \\
\text { ELISA }^{\text {\% }}\end{array}$ & Prev. $^{{ }^{1}}$ & Prev. $^{2}$ \\
\hline Bordering Argentina & 285 & 3.2 & 30.5 & 4.6 & 5 & 7 & $1.8 \%$ & $2.5 \%$ \\
Bordering Paraguay & 396 & 7.6 & 21.2 & 4.3 & 12 & 20 & $3.0 \%$ & $5.1 \%$ \\
\hline
\end{tabular}

Prev. $=$ Prevalence; ${ }^{1}=$ Protocol of Brazil Ministry of Health until 2012; ${ }^{2}=$ Protocol of Brazil Ministry of Health after 2012.

and $50 \%$ on the border of Paraguay), hens (23.9 and $16.7 \%$, respectively) and rats (37.5 and 20.2\%); organic matter was also observed due to the presence of gardens ( 40.4 and $45.7 \%$ ) and the accumulation of leaves (39.3 and 42.7\%).

Most of the domestic sewage was destined for the sewage network (52\% on the border of Argentina and $49.1 \%$ on the border of Paraguay) or for the septic tank (38.1\% on the border of Argentina and $47.8 \%$ on the border of Paraguay). Regarding the final destination of domestic waste, most of the households used the public collection system ( $88 \%$ on the border of Argentina and $94.4 \%$ on the border of Paraguay) (Table 4).

Of the dogs that tested as reagents based on an ELISA screening test and an IFA confirmatory test in the region bordering Argentina, two (2/5) had clinical signs: one had anorexia, weight loss and prostration; and the other had a skin lesion with a nodular aspect on the limb. With $\mathrm{DPP}^{\circledR}$ as a screening test and an ELISA confirmatory test, two (2/7) dogs showed clinical signs: one animal with anorexia, a skin lesion with alopecia, weight loss and prostration; and another with a skin lesion with raised borders on the limb and onychogryphosis.

In the region bordering Paraguay, one dog presented clinical signs of skin lesions and was reactive in an ELISA screening test and IFA confirmatory test $(1 / 12)$; the dog was also reactive with a DPP ${ }^{\circledR}$ screening test and an ELISA confirmatory test $(1 / 20)$.

\section{Discussion}

This study carried out in Foz do Iguaçu (PR), when based on the diagnosis criteria adopted by the Brazilian Ministry of Health until the year 2012 (ELISA as a screening test and IFA as 
Table 2. Epidemiological data and characteristics of the dogs analyzed in Foz do Iguaçu city, Paraná, on the border of Argentina, 2012.

\begin{tabular}{|c|c|c|c|c|c|c|}
\hline \multirow[b]{2}{*}{ Variables } & \multicolumn{3}{|c|}{ Prot. ${ }^{1}$} & \multicolumn{3}{|c|}{ Prot. $^{2}$} \\
\hline & $\begin{array}{l}\text { Seroreactive/ } \\
\text { Total }(\%)\end{array}$ & P-value & OR (95\%CI) & $\begin{array}{l}\text { Seroreactive/ } \\
\text { Total }(\%)\end{array}$ & P-value & OR (95\%CI) \\
\hline \multicolumn{7}{|l|}{ Place of residence } \\
\hline Urban area & $5 / 226(2.2)$ & $0.6553^{(1)}$ & & & & \\
\hline Rural area & $0 / 56(0.0)$ & & & 2/56 (11.2) & & \\
\hline \multicolumn{7}{|l|}{$\begin{array}{l}\text { Presence of woods close to } \\
\text { the household }\end{array}$} \\
\hline Yes & $4 / 241(1.7)$ & $>0.9999^{(1)}$ & Ind. ${ }^{* *}$ & $5 / 241(2.1)$ & $>0.9999^{(1)}$ & $0.62(0.07-5.44)$ \\
\hline No & $0 / 30(0.0)$ & & & $1 / 30(3.3)$ & & \\
\hline \multicolumn{7}{|l|}{$\begin{array}{l}\text { Distance of woods from } \\
\text { household }\end{array}$} \\
\hline 0-300 meters* & $0 / 117(0.0)$ & & & $4 / 117(3.4)$ & & \\
\hline $300-500$ meters & $3 / 50(6.0)$ & $0.0514^{(1)}$ & $0(0.0-1.01)$ & $0 / 50(0.0)$ & $0.4744^{(1)}$ & Ind.** \\
\hline More than 500 meters & $1 / 61(1.6)$ & $0.6854^{(1)}$ & $0(0.0-20.3)$ & $1 / 61(1.6)$ & $0.8810^{(1)}$ & $2.1(0.20-106.3)$ \\
\hline \multicolumn{7}{|l|}{ Presence of other animals } \\
\hline Yes & $4 / 201(2.0)$ & $>0.9999^{(1)}$ & $1.62(0.16-80.98)$ & $7 / 201(3.5)$ & $0.1813^{(1)}$ & Ind. ${ }^{* *}$ \\
\hline No & $1 / 81(1.2)$ & & & $0 / 81(0.0)$ & & \\
\hline \multicolumn{7}{|l|}{$\begin{array}{l}\text { Presence of organic } \\
\text { matter in the backyard }\end{array}$} \\
\hline Yes & $5 / 217(2.3)$ & $0.5533^{(1)}$ & Ind..$^{* *}$ & $6 / 217(2.8)$ & $>0.9999^{(1)}$ & $1.76(0.21-82.3)$ \\
\hline No & $0 / 63(0.0)$ & & & $1 / 63(1.6)$ & & \\
\hline \multicolumn{7}{|c|}{$\begin{array}{l}\text { Public collection of domes- } \\
\text { tic waste }\end{array}$} \\
\hline Yes & $5 / 241(2.08)$ & $>0.9999^{(1)}$ & Ind. ${ }^{* *}$ & $5 / 241(2.08)$ & $0.4020^{(1)}$ & $0.33(0.05-3.61)$ \\
\hline No & $0 / 33(0.0)$ & & & $2 / 33(6.1)$ & & \\
\hline \multicolumn{7}{|l|}{ Dog with identified breed } \\
\hline Yes & $1 / 62(1.6)$ & $>0.9999^{(1)}$ & $0.85(0.02-8.79)$ & $0 / 62(0.0)$ & $0.3220^{(1)}$ & $0.0(0.0-2.35)$ \\
\hline No & $4 / 211(1.9)$ & & & $7 / 211(3.3)$ & & \\
\hline \multicolumn{7}{|l|}{ Gender } \\
\hline Male & 2/139 (1.4) & $>0.9999^{(1)}$ & $0.67(0.06-5.97)$ & 5/139 (3.6) & $0.4355^{(1)}$ & $2.59(0.41-27.59)$ \\
\hline Female & $3 / 141(2.1)$ & & & 2/141 (1.4) & & \\
\hline \multicolumn{7}{|l|}{ Age group } \\
\hline$\leq 1$ year* & $0 / 54(0.0)$ & & & $0 / 54(0.0)$ & & \\
\hline $2 \nmid 8$ years & $4 / 199(2.0)$ & $0.7606^{(1}$ & $0(0.0-5.62)$ & $6 / 199(3.0)$ & $0.4659^{(1)}$ & $0(0.0-2.38)$ \\
\hline$>8$ years & $1 / 23(4.4)$ & $0.5974^{(1)}$ & $0(0.0-16.61)$ & $1 / 23(4.4)$ & $0.5974^{(1)}$ & $0(0.0-16.61)$ \\
\hline \multicolumn{7}{|l|}{$\begin{array}{l}\text { Dog came from another } \\
\text { city }\end{array}$} \\
\hline Yes & $0 / 18(0.0)$ & $>0.9999^{(1)}$ & $0(0.0-16.35)$ & $0 / 18(0.0)$ & $>0.9999^{(1)}$ & $0.0(0-10.43)$ \\
\hline No & $5 / 257(2.0)$ & & & $7 / 257(2.7)$ & & \\
\hline
\end{tabular}

Prot $.^{1}=$ Protocol of Brazil Ministry of Health until 2012; Prot $.^{2}=$ Protocol of Brazil Ministry of Health after 2012. ${ }^{*}=$ Reference category; ${ }^{* *}=$ Undefined. ${ }^{(1)}$ Fisher's exact test.

confirmatory), showed a anti-Leishmania spp. antibodies prevalence of $1.8 \%(5 / 285)$ on the border of Argentina whereas a prevalence of $3.0 \%$ (12/396) was found on the border of Paraguay. In a study conducted in São Borja, Rio Grande do Sul (RS), from February 2009 to December 2010, the prevalence was $22.5 \%$ in 5,400 dogs serological samples. In the same period, a prevalence of $14 \%$ was observed in dogs from Uruguaiana (RS), and a prevalence of $4.1 \%$ was observed in dogs from Porto Alegre (RS) (TARTAROTTI et al., 2011). Hirschmann et al. (2015) evaluated 165 dogs from kennels and non-governmental organizations (NGOs) from 12 cities in the state of Rio Grande do Sul, that were disease-free for cVL, and found a prevalence of $3.0 \%(5 / 165)$. In the state of Santa
Catarina, which borders the state of Paraná, Figueiredo et al. (2012) described the first autochthonous cVL cases in the city of Florianópolis. Afterwards, an epidemiological survey was conducted on 2,124 dogs from seven districts in the city of Florianópolis, and the prevalence was $1.4 \%(29 / 2,124)$ (STEINDEL et al., 2013). Maziero et al. (2014) showed a rate of $21 \%$ in the western part of the Santa Catarina border of Paraná state.

When the criterion adopted by the Ministry of Health was used in this study $\left(\mathrm{DPP}^{\circledR}\right.$ as a screening test and ELISA as a confirmatory test), an anti-Leishmania spp. antibodies prevalence of $2.5 \%$ (7/285) was found on the border of Argentina and 5.1\% (20/396) on the border of Paraguay. In the State of Rio Grande 
Table 3. Epidemiological data and characteristics of the dogs analyzed in Foz do Iguaçu city, Paraná, on the border of Paraguay, 2013.

\begin{tabular}{|c|c|c|c|c|c|c|}
\hline \multirow[b]{2}{*}{ Variables } & \multicolumn{3}{|c|}{ Prot. $^{1}$} & \multicolumn{3}{|c|}{ Prot. $^{2}$} \\
\hline & $\begin{array}{c}\text { Seroreactive/ } \\
\text { Total (\%) }\end{array}$ & P-value & OR $(95 \% C I)$ & $\begin{array}{c}\text { Seroreactive/ } \\
\text { Total (\%) }\end{array}$ & P-value & OR $(95 \% \mathrm{CI})$ \\
\hline \multicolumn{7}{|l|}{ Place of residence } \\
\hline Urban area & $10 / 364(2.8)$ & $0.5034^{(2)}$ & $0.43(0.08-4.17)$ & $16 / 364(4.4)$ & $0.1354^{(2)}$ & $0.32(0.10-1.42)$ \\
\hline Rural area & 2/32 (6.3) & & & 4/32 (12.5) & & \\
\hline \multicolumn{7}{|l|}{$\begin{array}{l}\text { Presence of woods close } \\
\text { to the household }\end{array}$} \\
\hline Yes & $11 / 345(3.2)$ & $>0.9999^{(2)}$ & $1.61(0.23-70.86)$ & $17 / 345(4.9)$ & $0.9526^{(2)}$ & $0.81(0.22-4.49)$ \\
\hline No & $1 / 50(5.0)$ & & & & & \\
\hline \multicolumn{7}{|l|}{$\begin{array}{l}\text { Distance of woods from } \\
\text { household }\end{array}$} \\
\hline 0-300 meters* & $7 / 158(4.4)$ & & & $11 / 158(7.0)$ & & \\
\hline $300-500$ meters & $2 / 97(2.1)$ & $0.5323^{(2)}$ & $2.2(0.41-22.1)$ & 6/97 (6.2) & $>0.9999^{(2)}$ & $1.13(0.34-3.87)$ \\
\hline More than 500 meters & $1 / 80(1.3)$ & $0.3718^{(2)}$ & $3.7(0.46-30.29)$ & $0 / 80(0.0)$ & $0.0195^{(2)}$ & Ind. ${ }^{* *}$ \\
\hline \multicolumn{7}{|l|}{ Presence of other animals } \\
\hline Yes & $6 / 253(2.4)$ & $0.4469^{(2)}$ & $0.54(0.14-2.08)$ & $10 / 253(4.0)$ & $0.2566^{(2)}$ & $0.54(0.19-1.48)$ \\
\hline No & $6 / 140(4.3)$ & & & $10 / 140(7.1)$ & & \\
\hline \multicolumn{7}{|l|}{$\begin{array}{l}\text { Presence of organic mat- } \\
\text { ter in the backyard }\end{array}$} \\
\hline Yes & $10 / 328(3.1)$ & $>0.9999^{(2)}$ & $1.02(0.21-9.81)$ & $17 / 328(5.2)$ & $>0.9999^{(2)}$ & $1.17(0.32-6.4)$ \\
\hline No & 2/67 (3.0) & & & $3 / 67(4.5)$ & & \\
\hline \multicolumn{7}{|l|}{$\begin{array}{l}\text { Public collection of do- } \\
\text { mestic waste }\end{array}$} \\
\hline Yes & 7/371 (1.9) & $0.0004^{(1)}$ & $0.07(0.02-0.30)$ & $14 / 371(3.8)$ & $0.0007^{(1)}$ & $0.11(0.03-0.38)$ \\
\hline No & $5 / 22(22.7)$ & & & 6/22 (27.3) & & \\
\hline \multicolumn{7}{|l|}{ Dog with identified breed } \\
\hline Yes & $4 / 144(2.8)$ & $>0.9999^{(2)}$ & $0.86(0.19-3.28)$ & $5 / 144(3.5)$ & $0.3838^{(1)}$ & $0.56(0.18-1.53)$ \\
\hline No & $8 / 249(3.2)$ & & & $15 / 249(6.0)$ & & \\
\hline \multicolumn{7}{|l|}{ Gender } \\
\hline Male & $6 / 181(3.3)$ & $0.9929^{(1)}$ & $1.19(0.36-3.98)$ & $10 / 181(5.5)$ & $0.8687^{(1)}$ & $1.20(0.48-3.29)$ \\
\hline Female & $6 / 215(2.8)$ & & & $10 / 215(4.7)$ & & \\
\hline \multicolumn{7}{|l|}{ Age group } \\
\hline$\leq 1$ year* & $0 / 69(0.0)$ & & & $1 / 69(1.5)$ & & \\
\hline $2 \nmid 8$ years & $9 / 277(3.3)$ & $0.2631^{(2)}$ & $0.0(0.0-2.02)$ & $16 / 277(5.8)$ & $0.2263^{(2)}$ & $0.24(0.01-1.6)$ \\
\hline$>8$ years & $3 / 49(6.1)$ & $0.1381^{(2)}$ & $0.0(0.0-1.69)$ & $3 / 49(6.1)$ & $0.2263^{(2)}$ & $0.23(0.004-2.9)$ \\
\hline \multicolumn{7}{|l|}{$\begin{array}{l}\text { Dog came from another } \\
\text { city }\end{array}$} \\
\hline Yes & $0.0 / 16(0.0)$ & $>0.9999^{(2)}$ & $0.0(0.0-9.79)$ & $0 / 16(0.0)$ & $0.8330^{(2)}$ & $0.0(0.0-4.90)$ \\
\hline No & $11 / 367(3.0)$ & & & $20 / 367(5.5)$ & & \\
\hline
\end{tabular}

do Sul, Hirschmann et al. (2015) reported a prevalence of $1.8 \%$. In endemic areas, prevalences of $3.1 \%$ and $9.2 \%$ were found in Campinas, state of São Paulo (VON ZUBEN et al., 2014) and the Federal District (HERENIO et al., 2014), respectively.

$\mathrm{DPP}^{\circledR}$ was developed to detect antibodies against rK26/rK39 antigens and shows high specificity (96\%) and low sensitivity (47\%) to identify dogs without clinical signs of VL. However, in the presence of signs, the sensitivity of the test increases (98\%) (GRIMALDI et al., 2012). According to Alves et al. (ALVES et al., 2012), the sensitivity and specificity rates remain high regardless of whether the animals are infected with Trypanosoma caninum.
The $\mathrm{DPP}^{\circledR}$ test as a screening test has an advantage over ELISA because of its easy manipulation and ability to show results in 15 minutes; therefore, it can be used in both the field and the laboratory (SANTIS et al., 2013).

Foz do Iguaçu did not conduct previous studies on leishmaniasis; however, studies conducted in other cities of Paraná demonstrated that the regions analyzed were disease-free for $\mathrm{cVL}$, a fact that allows us to affirm that the area where the study was performed in Foz do Iguaçu was not endemic (TEODORO et al., 2003, 2010; MEMBRIVE et al., 2004; THOMAZ-SOCCOL et al., 2009). The low prevalence showed in the $\mathrm{DPP}^{\circledR}$ test can be explained by the 
Table 4. Frequency of the characteristics of the environment and dogs analyzed in Foz do Iguaçu city, Paraná, on the border with Argentina and Paraguay, 2012 and 2013.

\begin{tabular}{|c|c|c|}
\hline \multirow[t]{2}{*}{ Variables } & \multicolumn{2}{|c|}{$\begin{array}{l}\text { Number (\%) of residences } \\
\text { on the International } \\
\text { border }\end{array}$} \\
\hline & Argentina & Paraguay \\
\hline \multicolumn{3}{|l|}{ Place of residence } \\
\hline Urban area & $226(80.1)$ & $364(91.9)$ \\
\hline Rural area & $56(19.9)$ & $32(8.1)$ \\
\hline \multicolumn{3}{|c|}{$\begin{array}{l}\text { Presence of woods close to the } \\
\text { household }\end{array}$} \\
\hline Yes & $241(88.9)$ & $345(87.3)$ \\
\hline No & $30(11.1)$ & $50(12.7)$ \\
\hline \multicolumn{3}{|c|}{ Distance of woods from household } \\
\hline $0-300$ meters & $117(51.3)$ & $158(47.2)$ \\
\hline $300-500$ meters & $50(21.9)$ & $97(28.9)$ \\
\hline More than 500 meters & $61(26.8)$ & $80(23.9)$ \\
\hline \multicolumn{3}{|l|}{ Presence of other animals } \\
\hline Yes & $201(71.3)$ & $253(64.4)$ \\
\hline No & $81(28.7)$ & $140(35.6)$ \\
\hline \multicolumn{3}{|l|}{ Type of animals } \\
\hline Wild animal & $32(11.2)$ & $4(1.0)$ \\
\hline Mouse & $8(2.8)$ & $8(2.0)$ \\
\hline Equine & $68(23.9)$ & $66(16.7)$ \\
\hline Hen & $55(19.3)$ & $21(5.3)$ \\
\hline Opossum & $63(22.1)$ & $198(50.0)$ \\
\hline Cat & $9(3.2)$ & $0(0.0)$ \\
\hline Monkey & $0(0.0)$ & $2(0.5)$ \\
\hline Mule & $107(37.5)$ & $80(20.2)$ \\
\hline \multicolumn{3}{|c|}{$\begin{array}{l}\text { Presence of organic matter in the } \\
\text { backyard }\end{array}$} \\
\hline Yes & $217(77.5)$ & $328(83.0)$ \\
\hline No & $63(22.5)$ & $67(17.0)$ \\
\hline \multicolumn{3}{|l|}{ Type of organic matter } \\
\hline Leaf accumulation & $112(39.3)$ & $169(42.7)$ \\
\hline Vegetable garden & $40(14.0)$ & $59(14.9)$ \\
\hline Garden & $115(40.4)$ & $181(45.7)$ \\
\hline Waste & $43(15.1)$ & $67(16.9)$ \\
\hline Orchard & $81(28.4)$ & $64(16.2)$ \\
\hline \multicolumn{3}{|l|}{ Dog with identified breed } \\
\hline Yes & $62(22.7)$ & $144(36.6)$ \\
\hline No & $211(77.3)$ & $249(63.4)$ \\
\hline \multicolumn{3}{|l|}{ Gender } \\
\hline Male & 139 (49.6) & $181(45.7)$ \\
\hline Female & $141(50.4)$ & $215(54.3)$ \\
\hline \multicolumn{3}{|l|}{ Age group } \\
\hline$\leq 1$ year & $54(19.6)$ & $69(17.5)$ \\
\hline $2 \dashv 8$ years & $199(72.1)$ & $277(70.1)$ \\
\hline$>8$ years & $23(8.3)$ & $49(12.4)$ \\
\hline \multicolumn{3}{|c|}{ Dog came from another city } \\
\hline Yes & $18(6.5)$ & $16(4.2)$ \\
\hline No & $257(93.5)$ & $367(95.8)$ \\
\hline
\end{tabular}

fact that Foz do Iguaçu is an area of low incidence of leishmaniasis cases and most canine cases were asymptomatic. Consequently, the $\mathrm{DPP}^{\circledR}$ test is likely not efficient for a non-endemic area.

Although some commercial kits are available, most information on the ELISA diagnostic performance comes from in-house tests (PALTRINIERI et al., 2010), which can be performed with crude, synthetic or recombinant antigens (MAIA \& CAMPINO, 2008), of which recombinant antigens shows the best results (MIRÓ et al., 2008; MARCONDES et al., 2011). Crude antigens provide a specificity of $87 \%$, whereas the recombinant antigens rK26 and A2 provide specificities of $90 \%$ and $96 \%$, respectively (PORROZZI et al., 2007). The advantage in the use of ELISA versus IFA is in its semi-automation, which eliminates the IFA subjectivity; moreover, ELISA is a technique that can be applied to a large number of samples in a short period of time (MAIA \& CAMPINO, 2008; LUCIANO et al., 2009).

IFA shows a sensitivity between $83 \%$ and $100 \%$ and a specificity of approximately $80 \%$. IFA requires specialized, high-cost equipment and trained staff due to the subjective interpretation in the evaluation of the fluorescence intensity by microscopy (EDRISSIAN \& DARABIAN, 1979; BARBOSA-DE-DEUS et al., 2002; PALTRINIERI et al., 2010; FARIA \& ANDRADE, 2012).

One of the main limitations of ELISA and IFA techniques is the occurrence of cross-reactions with other species of the Trypanosomatidae family, particularly Trypanosoma sp., due to the phylogenetic proximity between the species (CAMARGO \& REBONATO, 1969; CABALLERO et al., 2007; LUCIANO et al., 2009; PALTRINIERI et al., 2010). To reduce the risks of cross-reaction, the adsorption of sera with Trypanosoma sp. antigens could be made, but it is not routinely applicable.

The non-public collection of domestic waste was related as a risk factor for leishmaniasis. The presence of organic matter in the peridomicile represents the possible shelters and vector breeding sites and reflects the importance of the environment to maintain the parasite cycle (GONÇALVES, 2014). When there is regular waste collection, there is a lower leishmaniasis rate, which occurs because of the peridomicile reorganization and cleaning, leading to a reduction in the population of sand flies in these environments and, thus, reducing the risk of transmission of Leishmania to humans and domestic animals (MEMBRIVE et al., 2004; LAINSON \& RANGEL, 2005).

Most leishmaniasis cases in dogs were autochthonous with the residence located in urban areas and close to the woods. In Brazil, VL was first considered a rural disease; however, since the 1980s, it has been spreading to urban areas (WERNECK, 2014) where dogs are considered the main reservoir of the parasite (MARCONDES \& ROSSI, 2013). Environmental degradation, migratory flows and unplanned urban occupation favor the adaptation of vectors in the environment (SILVA et al., 2015). Acosta et al. (2015) reported that VL in Puerto Iguazú, Argentina was established due to changes in the urbanization of the vector and the existence of reservoirs (dogs) and vectors (Lu. longipalpis). Moreover, the geographical position of the city (triple border region) with tourist flow throughout the year nearby Iguazu National Park (Iguazu Falls) contributes to the spread of the disease.

The presence of other animals, mainly cats, chickens and rats, was observed in the analyzed residences. In some areas, dogs are not the preferred source of blood of $L u$. longipalpis (MARCONDES \& ROSSI, 2013), and the etiologic agent can remain naturally harbored in wild animals (SCHIMMING \& PINTO E SILVA, 2012). Afonso et al. (2012) found evidence of natural infection by L. infantum in opossums and found that these animals were feeding sources for the vector. The authors report the possibility that this 
synanthropic mammal participates in the VL transmission cycle in some regions, particularly those that experienced environmental changes, which facilitates the contact of these animals with human habitation. Controlling the invasion of urban areas by wild animals in search of food are control measures that can be adopted by the community, reducing the link between urban and wild cycles (SCHIMMING \& PINTO E SILVA, 2012).

An integrated surveillance system involves human and animal health and wildlife sectors working together to detect unusual disease events that trigger a response to contain and control intervention measures (HÄSLER et al., 2012). This context fits into the One Health concept, with the premise that people, animals and the environment form an interdependent ecosystem that must be considered in a coordinated way (FRANK, 2008; GIBBS, 2014). To achieve this system, a clear leadership and coordination, common goals and objectives, tools for data collection and analysis, integrated contingency plans and a good field communication are required (HÄSLER et al., 2012).

The data obtained in the present study demonstrate the presence of leishmaniasis and suggest the emergence of cVL in Foz do Iguaçu in the tri-border area with Argentina and Paraguay, which presents population characteristics (tourist and commercial region, intense flow of people and animals), environmental (residences with accumulation of organic matter and near to woods), and the presence of autochthonous dogs. All these factors must collaborate in the maintenance of the zoonosis and provide subsidies for a One Health approach.

Since 2013, the technical collaboration of the Pan American Health Organization has assisted in the adoption of strategies in this work, and it has been verified that joint measures with integrated and transdisciplinary eco-socio-systemic approaches must be adopted among the countries to achieve VL control. Thus, prevention and control measures at the local, regional, national and international levels should be conducted in an uniform manner by standardizing collection, processing and analysis of samples, and approaching ecological, epidemiological and socio-cultural variables of interest at these levels and defining control strategies and programs in the three countries.

\section{Acknowledgements}

First, we would like to thank the dog owners who participated in this study. The authors are grateful for the unremitting willingness of each student, researcher, technician and professional involved in the sample collection and processing, and in the oversight and management of the research. We particularly thank the Pan American Health Organization (PAHO/WHO); Ivana Lúcia Belmonte, Ricardo Matsuo, and Thaila Francine Corona from the Paraná State Health Secretariat (SESA-PR), Brazil; André de Souza Leandro from the Zoonoses Control Center in Foz do Iguaçu city, Brazil; Lígia Moraes Barizon de Souza from the Federal University of Paraná, Brazil; and Aldair Calistro de Mattos, Alessandra Taroda, Aline do Nascimento Benitez, Beatriz de Souza Lima Nino, Célia Rosimarie dos Reis, Elizabete Regina Marangoni Marana, Eloiza Teles Caldart, Fernanda Evers, Hannah Lia Ettiene Peruch Lemos dos Santos, Helenice Kieski, Jonatas Campos de Almeida, Laura
Helena França de Barros Bittencourt, Luiz Daniel de Barros, Maria Paula Ewald, Sthefany Pagliari, and Victor Bittencourt Dutra Tabacow from Londrina State University.

\section{References}

Acosta L, Díaz R, Torres P, Silva G, Ramos M, Fattore G, et al. Identification of Leishmania infantum in Puerto Iguazú, Misiones, Argentina. Rev Inst Med Trop Sao Paulo 2015; 57(2): 175-176. PMid:25923899.

Afonso MMS, Duarte R, Miranda JC, Caranha L, Rangel EF. Studies on the feeding habits of Lutzomyia (Lutzomyia) longipalpis (Lutz \& Neiva, 1912) (Diptera: Psychodidae: Phlebotominae) populations from endemic areas of American Visceral Leishmaniasis in Northeastern Brazil. J Trop Med 2012; 2012:1-5. PMid:22315621.

Alves AS, Mouta-Confort E, Figueiredo FB, Oliveira RVC, Schubach AO, Madeira MF. Evaluation of serological cross-reactivity between canine visceral leishmaniasis and natural infection by Trypanosoma caninum. Res Vet Sci 2012; 93(3): 1329-1333. PMid:22840335.

Ashford RW. Leishmaniasis reservoirs and their significance in control. Clin Dermatol 1996; 14(5): 523-532. PMid:8889331.

Barbosa-De-Deus R, Mares-Guia ML, Nunes AZ, Costa KM, Junqueira RG, Mayrink W, et al. Leishmania major-like antigen for specific and sensitive serodiagnosis of human and canine visceral leishmaniasis. Clin Diagn Lab Immunol 2002; 9(6): 1361-1366. PMid:12414775.

Barroso PA, Marco JD, Locatelli FM, Cardozo RM, Hoyos CL, Mora MC, et al. Visceral Leishmaniasis Caused by Leishmania infantum in Salta, Argentina: Possible Reservoirs and Vectors. Am J Trop Med Hyg 2015; 93(2): 334-339. PMid:26055744.

Brasil. Ministério da Saúde, Secretaria de Vigilância em Saúde, Departamento de Vigilância Epidemiológica. Manual de vigilância e controle da leishmaniose visceral [online]. Brasília; 2006. [cited 2018 May 1]. p. 9-18. Available from: http://bvsms.saude.gov.br/bvs/publicacoes/ manual_vigilancia_controle_leishmaniose_visceral.pdf

Brasil. Ministério da Saúde, Secretaria de Vigilância em Saúde, Departamento de Vigilância das Doenças Transmissíveis. Nota técnica conjunta $n^{\circ} 01$. Esclarecimentos sobre substituição do protocolo diagnóstico da leishmaniose visceral canina (LVC) [online]. Brasília: Ministério da Saúde; 2011 [cited 2018 May 1]. Available from: http://www.sgc.goias.gov.br/upload/ arquivos/2012-05/nota-tecnica-no.-1-2011_cglab_cgdt1_lvc.pdf

Caballero ZC, Sousa OE, Marques WP, Saez-Alquezar A, Umezawa ES. Evaluation of serological tests to identify Trypanosoma cruzi infection in humans and determine cross-reactivity with Trypanosoma rangeli and Leishmania spp. Clin Vaccine Immunol 2007; 14(8): 1045-1049. PMid:17522327.

Camargo ME, Rebonato C. Cross-reactivity in fluorescence tests for Trypanosoma and Leishmania antibodies. A simple inhibition procedure to ensure specific results. Am J Trop Med Hyg 1969; 18(4): 500-505. PMid:4978596.

Canese J. Gran incremento de Leishmaniasis visceral humana en Paraguay. Pediatr 2010; 37(3): 167-168.

Costa CHN. How effective is dog culling in controlling zoonotic visceral leishmaniasis? A critical evaluation of the science, politics and ethics behind this public health policy. Rev Soc Bras Med Trop 2011; 44(2): 232-242. PMid:21468480. 
Dantas-Torres F. The role of dogs as reservoirs of Leishmania parasites, with emphasis on Leishmania (Leishmania) infantum and Leishmania (Viannia) braziliensis. Vet Parasitol 2007; 149(3-4): 139-146. PMid:17703890.

Dean AG, Dean JA, Coulombier D, Brendel KA, Smith DC, Burton $\mathrm{AH}$, et al. Epi Info, Version 6: a word processing, database, and statistics program for epidemiology on microcomputers. Atlanta: Center for Diseases Control and Prevention; 1994.

Edrissian GH, Darabian P. A comparison of enzyme-linked immunosorbent assay and indirect fluorescent antibody test in the sero-diagnosis of cutaneous and visceral leishmaniasis in Iran. Trans R Soc Trop Med Hyg 1979; 73(3): 289-292. PMid:382470.

Faria AR, Andrade HM. Diagnóstico da Leishmaniose Visceral Canina: grandes avanços tecnológicos e baixa aplicação prática. Rev Pan-Amaz Saúde 2012; 3(2): 47-57.

Figueiredo FB, Lima Júnior FEF, Tomio JE, Indá MC, Corrêa GLB, Madeira MF. Leishmaniose Visceral Canina: Dois casos autóctones no município de Florianópolis, estado de Santa Catarina. Acta Sci Vet 2012; 40(1): 1-4.

Foz do Iguaçu. Portal do Turismo [online]. Foz do Iguaçu; 2017 [cited 2017 Aug 22]. Available from: http://www.pmfi.pr.gov.br/turismo/

Frank D. One world, one health, one medicine. Can Vet J 2008; 49(11): 1063-1065. PMid:19183729.

Gibbs EPJ. The evolution of One Health: a decade of progress and challenges for the future. Vet Rec 2014; 174(4): 85-91. PMid:24464377.

Gonçalves MB. Prevalência, distribuição e identificação de prováveis fatores de risco para leishmaniose visceral canina em Camaçari-BA [dissertação]. Salvador: Fundação Oswaldo Cruz; 2014.

Gould IT, Perner MS, Santini MS, Saavedra SB, Bezzi G, Maglianese MI, et al. Leishmaniasis visceral en la Argentina. Notificación y situación vectorial (2006-2012). Med (Buenos Aires) 2013; 73(2): 104-110.

Grimaldi G Jr, Teva A, Ferreira AL, Santos CB, Pinto I, Azevedo CT, et al. Evaluation of a novel chromatographic immunoassay based on Dual-Path Platform technology (DPP ${ }^{\circledR}$ CVL rapid test) for the serodiagnosis of canine visceral leishmaniasis. Trans R Soc Trop Med Hyg 2012; 106(1): 54-59. PMid:22137538.>

Häsler B, Gilbert W, Jones BA, Pfeiffer DU, Rushton J, Otte MJ. The economic value of one health in relation to the mitigation of zoonotic disease risks. Curr Top Microbiol Immunol 2012; 365: 127-151. PMid:24264885.

Herenio EM, Fortes RC, Rincon G. Prevalência da Leishmaniose visceral em cães do Distrito Federal, segundo dados do centro de zoonoses de Brasília. J Health Sci Inst 2014; 32(2): 126-129.

Hirschmann LC, Brod CS, Radin J, Simon CF, Recuero ALC. Leishmaniose visceral canina: comparaçáo de métodos sorológicos em cães de área indene do Rio Grande do Sul no Brasil. Rev Patol Trop 2015; 44(1): 33-44.

Instituto Brasileiro de Geografia e Estatística - IBGE. Estimativas da população residente nos municípios brasileiros com data de referência em $1^{\circ}$ de julho de 2012 [online]. Brasília: Instituto Brasileiro de Geografia e Estatísticas; 2012 [cited 2017 Aug 22]. Available from: ftp://ftp.ibge. gov.br/Estimativas_de_Populacao/Estimativas_2012/estimativa_2012_ municipios.pdf

Instituto Brasileiro de Geografia e Estatística - IBGE. Estimativas da população residente nos municípios brasileiros com data de referência em $1^{\circ}$ de julho de 2013 [online]. Brasília: Instituto Brasileiro de Geografia e Estatísticas; 2013 [cited 2017 Aug 22]. Available from: ftp://ftp.ibge.gov. br/Estimativas_de_Populacao/Estimativas_2013/estimativa_2013_dou.pdf
Instituto Brasileiro de Geografia e Estatística - IBGE. Cidades - Parana - Foz do Iguaçu [online]. Instituto Brasileiro de Geografia e Estatística; 2016 [cited 2017 Aug 22]. Available from: https://cidades.ibge.gov.br/ brasil/pr/foz-do-iguacu

Lainson R, Rangel EF. Lutzomyia longipalpis and the eco-epidemiology of American visceral leishmaniasis, with particular reference to Brazil: a review. Mem Inst Oswaldo Cruz 2005; 100(8): 811-827. PMid:16444411.

Lainson R, Shaw JJ. Evolution, classification and geographical distribution. In: Peters W, Killick-Kendrick R. The leishmaniases in biology and medicine. London: Academic Press; 1987. p. 1-120.

Luciano RM, Lucheis SB, Troncarelli MZ, Luciano DM, Langoni H. Avaliação da reatividade cruzada entre antígenos de Leishmania spp e Trypanosoma cruzi na resposta sorológica de cáes pela técnica de imunofluorescência indireta (RIFI). Braz J Vet Res Anim Sci 2009; 46(3): 181-187.

Maia C, Campino L. Methods for diagnosis of canine leishmaniasis and immune response to infection. Vet Parasitol 2008; 158(4): 274-287. PMid:18789583.

Marcondes M, Biondo AW, Gomes AAD, Silva ARS, Vieira RFC, Camacho AA, et al. Validation of a Leishmania infantum ELISA rapid test for serological diagnosis of Leishmania chagasi in dogs. Vet Parasitol 2011; 175(1-2): 15-19. PMid:21030153.

Marcondes M, Rossi CN. Leishmaniose visceral no Brasil. Braz J Vet Res Anim Sci 2013; 50(5): 341-352.

Marzochi MCA, Coutinho SG, Sabroza PC, Souza WJS. Reação de imunofluorescência indireta e intradermorreação para leishmaniose tegumentar americana em moradores na área de Jacarepaguá (Rio de Janeiro). Estudo comparativo dos resultados observados em 1974 e 1978 Rev do Inst Med Trop 1980; 22(3): 97-155.

Maziero N, Thomaz-Soccol V, Steindel M, Link JS, Rossini D, Alban $\mathrm{SM}$, et al. Rural-urban focus of canine visceral leishmaniosis in the far western region of Santa Catarina State, Brazil. Vet Parasitol 2014; 205(12): 92-95. PMid:25023635.

Membrive NA, Rodrigues G, Membrive U, Monteiro WM, Neitzke HC, Lonardoni MVC, et al. Flebotomíneos de municípios do norte do estado do Paraná, sul do Brasil. Entomol Vectores 2004; 11(4): 673-680.

Miró G, Cardoso L, Pennisi MG, Oliva G, Baneth G. Canine leishmaniosis: new concepts and insights on an expanding zoonosis: part two. Trends Parasitol 2008; 24(8): 371-377. PMid:18603476.

Nicolle CJ. Sur trois cas d'infection splénique infantile à corps de Leishman observes en Tunisie. Les Arch l'Institut Pasteur Tunis 1908; 3: 1-26.

Ortiz RC, Anversa L. Epidemiologia da leishmaniose visceral em Bauru, São Paulo, no período de 2004 a 2012: um estudo descritivo. Epidemiol Serv Saude 2015; 24(1): 97-104.

Paltrinieri S, Solano-Gallego L, Fondati A, Lubas G, Gradoni L, Castagnaro $\mathrm{M}$, et al. Guidelines for diagnosis and clinical classification of leishmaniasis in dogs. J Am Vet Med Assoc 2010; 236(11): 1184-1191. PMid:20513195.

Paraguay. Ministerio de Salud Pública y Bienestar Social Organización Panamericana de la Salud. Manual Diagnóstico y Tratamiento de las Leishmaniosis. [online]. Asunción: OPS/OMS; 2011 [cited $2018 \mathrm{Mar}$ 18]. Available from: http://iris.paho.org/xmlui/handle/123456789/10102

Porrozzi R, Santos da Costa MV, Teva A, Falqueto A, Ferreira AL, Santos $\mathrm{CD}$, et al. Comparative evaluation of enzyme-linked immunosorbent assays based on crude and recombinant leishmanial antigens for serodiagnosis of 
symptomatic and asymptomatic Leishmania infantum visceral infections in dogs. Clin Vaccine Immunol 2007; 14(5): 544-548. PMid:17314229.

Ready PD. Epidemiology of visceral leishmaniasis. Clin Epidemiol 2014; 6: 147-154. PMid:24833919.

Salomón O, Sinagra A, Nevot MC, Barberian G, Paulin P, Estevez JO, et al. First visceral leishmaniasis focus in Argentina. Mem Inst Oswaldo Cruz 2008; 103(1): 109-111. PMid:18368242.

Salomón OD, Fernández MS, Santini MS, Saavedra S, Montiel N, Ramos MA, et al. Distribución de Lutzomyia longipalpis en la Mesopotamia Argentina, 2010. Med (Buenos Aires) 2011; 71(1): 22-26. PMid:21296716.

Santis B, Santos EGB, Souza CSF, Chaves SAM. Performance of $\mathrm{DPP}^{\mathrm{TM}}$ immunochromathographic rapid test (IRT) for canine visceral leishmaniasis:comparison with other serological methods in suspected dogs from Cuiabá, Mato Grosso State, Brazil. Braz J Vet Res Anim Sci 2013; 50(3): 198-205.

Santos DR, Ferreira AC, Bisetto A Jr. The first record of Lutzomyia longipalpis (Lutz \& Neiva, 1912) (Diptera: Psychodidae: Phlebotominae) in the State of Paraná, Brazil. Rev Soc Bras Med Trop 2012; 45(5): 643645. PMid:23152351.

Schimming BC, Pinto e Silva JRC. Leishmaniose visceral canina: revisão de literatura. Rev Cient Elet Med Vet 2012; 10(19): 1-17.

Silva DA, Madeira MF, Figueiredo FB. Geographical expansion of canine visceral leishmaniasis in Rio de Janeiro State, Brazil. Rev Inst Med Trop Sao Paulo 2015; 57(5): 435-438. PMid:26603233.

Souza GD, Santos E, Andrade JD Fo. The first report of the main vector of visceral leishmaniasis in America, Lutzomyia longipalpis (Lutz \& Neiva) (Diptera: Psychodidae: Phlebotominae), in the state of Rio
Grande do Sul, Brazil. Mem Inst Oswaldo Cruz 2009; 104(8): 11811182. PMid:20140381.

Steindel M, Menin Á, Evangelista T, Stoco PH, Marlow MA, Fleith $\mathrm{RC}$, et al. Outbreak of autochthonous canine visceral leishmaniasis in Santa Catarina, Brazil. Pesq Vet Bras 2013; 33(4): 490-496.

Tartarotti AL, Doninil MA, Anjos C, Ramos RR. Vigilância de reservatórios caninos. Bol Epidemiológico 2011; 13(1): 3-6.

Teodoro U, Alberton D, Kühl JB, Santos ES, Santos DR, Santos AR, et al. Ecologia de Lutzomyia (Nyssomyia) whitmani em área urbana do município de Maringá, Paraná. Rev Saude Publica 2003; 37(5): 651656. PMid:14569343.

Teodoro U, Santos DR, Silva AM, Massafera R, Imazu LE, Monteiro WM, et al. Fauna de flebotomíneos em municípios do norte pioneiro do estado do Paraná, Brasil. Rev Patol Trop 2010; 39(4): 322-330.

Tomaz-Soccol V, Castro EA, Navarro IT, Farias MR, Souza LM, Carvalho Y, et al. Casos alóctones de leishmaniose visceral canina no Paraná, Brasil: implicações epidemiológicas. Rev Bras Parasitol Vet 2009; 18(3): 46-51. PMid:19772775.

von Zuben APB, Angerami RN, Castagna C, Baldini MBD, Donalisio MR. The first canine visceral leishmaniasis outbreak in Campinas, State of São Paulo Southeastern Brazil. Rev Soc Bras Med Trop 2014; 47(3): 385-388. PMid:25075492.

Werneck GL. Visceral leishmaniasis in Brazil: rationale and concerns related to reservoir control. Rev Saude Publica 2014; 48(5): 851-856. PMid:25372177. 